\title{
Evaluation of Physical and Chemical Composition of Mango Varieties for Nectar and pana
}

\author{
Romila Xess ${ }^{1 *}$, Arunima Tripathi' ${ }^{2}$, Meeta Bhuarya ${ }^{3}$ and Dileep Sahu ${ }^{3}$ \\ ${ }^{1}$ Horticulture (Fruit Science), Department of Fruit Science College of Agriculture IGKV \\ Raipur Chhattisgarh, 492012, India \\ ${ }^{2}$ Rajmohini Devi College of Agriculture and Research Station Ambikapur, \\ Chhattisgarh, 497001, India \\ ${ }^{3}$ Horticulture (Fruit Science), Department of fruit Science College of Agriculture IGKV \\ Raipur, Chhattisgarh, 492012, India
}

*Corresponding author

\begin{abstract}
A B S T R A C T
Mango is acknowledged as the king of fruit and one of the best fruits in the world market because of its great utility, excellent flavour, attractive fragrance, and beautiful shades of colour, delicious taste and healthful value. The nutritive value of fruit beverage is better than synthetic ones. Looking at the demand there is a great scope in the country for production of fruit juices and other fruit based beverages. Ten varieties of mango were chosen and were processed followed by statistical analysis done. Maximum fruit weight and pulp weight was recorded $380 \mathrm{~g}$ and $266.76 \mathrm{~g}$, respectively, from Kakna (local) which was 70.2 per cent of the total fruit weight. The seed weight and non-edible waste in mango fruit were recorded $74.17 \mathrm{~g}$ and $155.52 \mathrm{~g}$ respectively. The calculated value of these two parameters are 19.51 per cent and 40.92 per cent, respectively of total fruit weight, whereas pulp:seed ratio was calculated 4.38 maximum for Dashehari. Data with respect to chemical composition of fruits revealed that maximum value of total soluble solids (TSS) was recorded $22^{\circ} \mathrm{Brix}$ from Mallika. The maximum value of total sugar and non-reducing sugar content was recorded 17.81 per cent, 13.81 per cent respectively from Mallika The maximum value of ascorbic acid content was recorded $56.34 \mathrm{mg} / 100 \mathrm{ml}$ from Langra. Whereas maximum titrable acidity was recorded 0.35 per cent from totapari, $\mathrm{pH}$ value was recorded maximum 3.75 in Totapari. A little attention has been made so far in the field of fruit processing technology in Chhattisgarh region. Hence, there is an urgent need to evaluate different varieties of mango for different preserved products of mango.
\end{abstract}

\section{Introduction}

Mango (Mangifera indica L.) is known as the king of fruits and belongs to the family
Anacardiaceae. Mango is well adapted to Chhattisgarh with wide genetic variation. Most of the area of Chhattisgarh is rain fed and vast acreage has an immense potential to 
improve mango production. Mango is the most popular fruit among millions of people of country and is considered to be the best of all the indigenous fruits in India. It is considered as one of the best fruits in the world market because of its great utility, excellent flavour, attractive fragrance, beautiful shades of colour, delicious taste, healthful value and high nutritional values. Carbohydrate content in ripe mango pulp is $16.9 \%$. Mango helps to prevent many deficiency diseases because it is a rich source of vitamins, minerals, acid, total soluble solids. If fruit juices will be sustained for synthetic products it will be beneficial to consumers as well as to the fruit growers. Careless and improper handling of fruits reduce the market value and keeping quality, ultimately causing enormous losses to both growers and consumers. Besides these quantitative losses, the loss suffered in quality before actual consumption can hardly be estimated. The spoilage could be prevented during the glut season at the producing centers by converting them into new categories of processed products. Looking at the demand there is a great scope in the country for production of fruit juices and other fruit based beverages. Keeping the above points in view, an experiment have been conducted to study the physico-chemical composition of nectar and pana.

\section{Materials and Methods}

The present investigation was conducted in the Horticulture Processing Laboratory Department of Fruit Science, College of Agriculture, Indira Gandhi Agricultural University, Raipur (C.G.) during the year 2017-18. Total ten varieties were studied Amrapali, Amin, Chausa, Dashehari, Kakna, Krishn bhog, Langra, Mallika, Sundri and Totapari. Mature mangoes were washed in running tap water to remove dirt and dust particles. They were sliced into small pieces.
The fruits were then cooked in boiling water for $15 \mathrm{~min}$. The cooked fruits were peeled manually and carefully to minimize pulp loss with the peels. The pulping was done using the domestic mixer grinder and the stone was collected separately. The beverage contained 20 per cent pulp for nectar and 10 per cent pulp for mango beverage (pana) was taken. The volume of the final product was maintained by adding water to each recipe combination in each replication. A calculated amount of sugar was added in the pulp to adjust the total soluble solids as 18 per cent in the recipe for nectar and as 15 per cent for RTS. The acidity was maintained to 0.3 per cent in the final product by the addition of required amount of citric acid. The product was poured into hot, sterilized crown bottles of $200 \mathrm{ml}$ capacity and corked air-tight. The filled bottles were pasteurized in boiling water till the temperature of product reaches $100^{\circ} \mathrm{C}$. It took about 15 minutes to attain required temperature. The bottles of nectar and pana beverages were kept at ambient condition for further studies up to 90 days (Fig. 1).

\section{Results and Discussion}

\section{Physical composition}

A critical analysis of data on physical composition of mango fruits revealed that maximum fruit weight and pulp weight was recorded $380 \mathrm{~g}$ and $266.76 \mathrm{~g}$, respectively, from Kakna (local) which was 70.2 per cent of the total fruit weight (Table 1).

\section{Chemical composition}

Data with respect to chemical composition of fruits revealed that maximum value of total soluble solids (TSS) was recorded $22^{0}$ Brix from Mallika (Table 2).

A critical analysis of data on physical composition of mango fruits revealed that 
maximum fruit weight and pulp weight was recorded $380 \mathrm{~g}$ and $266.76 \mathrm{~g}$, respectively, from Kakna (local) which was 70.2 per cent of the total fruit weight. The seed weight and nonedible waste in mango fruit were recorded $74.17 \mathrm{~g}$ and $155.52 \mathrm{~g}$ respectively. The calculated value of these two parameters are 19.51 per cent and 40.92 per cent, respectively of total fruit weight, whereas pulp:seed ratio was calculated 4.38 maximum for Dashehari. Roshan et al., (2013) reported that 'Moovandan' had the greatest breadth (7.52 $\mathrm{cm})$, circumference $(19.9 \mathrm{~cm})$, fruit weight $(231.3 \mathrm{~cm})$, volume $(228.4 \mathrm{ml})$ and juice content $(49.0 \mathrm{ml})$. The highest pulp percentage $(67.1 \%)$, the lowest stone percentage $(16.3 \%)$, and peel percentage $(22.5 \%)$ were recorded with Vellaicolamban'. Chopra (2014) reported that the skin colour of Dashehari was attractive greenish-yellow. The cultivars differed significantly in terms of fruit weight $(110.0-574.5 \mathrm{~g})$, length $(7.18-14.59 \mathrm{~cm})$, breadth $(5.23-9.07 \mathrm{~cm})$, specific gravity (0.953-1.061) content of flesh (58.18-79.90 $\%)$, peels (9.10-22.52\%) and stone (11.05$20.55 \%$ ). Manchekar et al., (2011) observed Cluster I, of Alphonso clone consists of the clones DPL-I, RTNI, DEV-1, VEN-1, DWR-I, DWD-II, DWD-III and BGM-II had the highest length of fruit $(14.37 \mathrm{~cm})$, stone thickness $(2.24 \mathrm{~cm})$, percentage of pulp (71.58), pulp to stone ratio $(4.75: 1)$, pulp to peel Ratio (5.21:1) and shelf life (19.85 days). Anila and Radha (2003) evaluated the physical, morphological and biochemical characters of four varieties made under Kerala conditions. It was observed that Ratna fruits had the maximum length, breadth, weight, volume and circumference. All this differ from our findings which could be due to the geographical distribution of mango varieties.

Data with respect to chemical composition of fruits revealed that maximum value of total soluble solids (TSS) was recorded $22^{0} \mathrm{Brix}$ from Mallika. The maximum value of total sugar and non-reducing sugar content was recorded 17.81 per cent, 13.81 per cent respectively from Mallika The maximum value of ascorbic acid content was recorded $56.34 \mathrm{mg} / 100 \mathrm{ml}$ from Langra. Whereas maximum titrable acidity was recorded 0.35 per cent from totapari, $\mathrm{pH}$ value was recorded maximum 3.75 in Totapari.

Jain et al., (1997) conducted the studies to evaluate the performance of 6 early maturing mango cultivars (Amin, Bombay green, Dashehari, Kurukkan, Ranipasand and Sunderja) in the Chhattisgarh region of eastern Madhya Pradesh for the preparation of mango nectar and RTS (ready to serve) beverages. During storage of nectar and RTS, the TSS, acidity and viscosity remained unchanged, but the ascorbic acid content was reduced, and reducing sugars increased. The quality of the mango RTS and nectar during storage remained acceptable for 3 and 4 months, respectively.

Rabbani and Singh (1989) studied seven sucking mango varieties and these were assessed for flavour, total soluble solids, acidity, reducing and non reducing sugar, vitamin $\mathrm{A}$ and $\mathrm{C}$. The fruits were processed as a ready to serve beverage $10 \%$ juice, $14 \%$ TSS, $\quad 0.3 \%$ acidity, nectar $(20 \%$ juice, $14 \%$, TSS, $0.3 \%$,acidity).

Roy et al., (1972) have standardized preparation of mango nectar with 20 per cent mango pulp, $20^{\circ}$ brix and 0.3 percent acidity.

According to Shetty et al., (1978) canned mango nectar was prepared taking 20 per cent mango pulp, 15 per cent total soluble solids with 0.3 percent acidity.

Singh and Dhawan (1983) reported that the ideal recipe for preparation of nectar for mango contains 20 per cent pulp, 14 per cent TSS and 0.3 percent acidity. 
Int.J.Curr.Microbiol.App.Sci (2018) 7(11): 2622-2627

Table.1 Physical composition of mango varieties

\begin{tabular}{|c|c|c|c|c|c|c|c|c|c|c|c|}
\hline \multirow[t]{2}{*}{ S.No. } & \multirow{2}{*}{$\begin{array}{l}\text { Varieties } \\
\text { Name }\end{array}$} & \multirow{2}{*}{$\begin{array}{l}\text { Fruit } \\
\text { weight } \\
\text { (g) }\end{array}$} & \multirow{2}{*}{$\begin{array}{c}\text { Seed } \\
\text { weight } \\
\text { (g) }\end{array}$} & \multirow{2}{*}{$\begin{array}{c}\text { Peel } \\
\text { weight } \\
\text { (g) }\end{array}$} & \multirow{2}{*}{$\begin{array}{l}\text { Pulp } \\
\text { weight } \\
\text { (g) }\end{array}$} & \multirow{2}{*}{$\begin{array}{c}\text { Wt. of } \\
\text { non } \\
\text { edible } \\
\text { waste (g) }\end{array}$} & \multirow{2}{*}{$\begin{array}{l}\text { Pulp: } \\
\text { Seed } \\
\text { ratio }\end{array}$} & \multicolumn{4}{|c|}{$\%$ of total fruit weight } \\
\hline & & & & & & & & Seed & peel & pulp & $\begin{array}{l}\text { Non- } \\
\text { edible } \\
\text { waste }\end{array}$ \\
\hline 1. & Amrapali & 110 & 20.6 & 22.5 & 72.1 & 43.1 & 3.5 & 18.7 & 20.4 & 65.6 & 39.2 \\
\hline 2. & Amin & 118 & 23.8 & 21.3 & 75.7 & 45.1 & 3.1 & 20.1 & 18 & 64.1 & 38.2 \\
\hline 3. & Chausa & 282.8 & 49.5 & 42.8 & 186.7 & 92.3 & 3.7 & 17.5 & 15.1 & 66 & 32.6 \\
\hline 4. & Dashehari & 164 & 25 & 30 & 109.7 & 55 & 4.3 & 15.2 & 18.3 & 66.9 & 33.5 \\
\hline 5. & $\begin{array}{l}\text { Kakna } \\
\text { (local) }\end{array}$ & 380 & 74.1 & 81.3 & 266.7 & 155.5 & 3.5 & 19.5 & 21.4 & 70.2 & 40.9 \\
\hline 6. & Krishnbhog & 118 & 22.9 & 23.9 & 76.2 & 46.8 & 3.3 & 19.4 & 20.3 & 64.5 & 39.7 \\
\hline 7. & Langra & 218 & 40.9 & 29.7 & 139.8 & 70.7 & 3.4 & 18.7 & 13.6 & 64 & 32.4 \\
\hline 8. & Mallika & 168 & 34.1 & 29 & 106.6 & 63.1 & 3.1 & 20.2 & 17.2 & 63.5 & 37.5 \\
\hline 9. & Sundri & 110 & 21.2 & 18.1 & 72.1 & 39.4 & 3.3 & 19.2 & 16.4 & 65.1 & 35.6 \\
\hline 10. & Totapari & 198 & 40.5 & 28.5 & 123.3 & 69.1 & 3.0 & 20.5 & 14.3 & 62.3 & 34.8 \\
\hline
\end{tabular}

Table.2 Chemical composition of mango varieties

\begin{tabular}{|l|l|c|c|c|c|c|c|c|}
\hline S.No. & $\begin{array}{l}\text { Varieties } \\
\text { Name }\end{array}$ & TSS & Acidity(\%) & $\begin{array}{c}\text { Ascorbic } \\
\text { acid(mg/100ml) }\end{array}$ & pH & $\begin{array}{c}\text { Reducing } \\
\text { sugar } \\
(\mathbf{\%})\end{array}$ & $\begin{array}{c}\text { Non- } \\
\text { reducing } \\
\text { sugar } \\
(\mathbf{\%})\end{array}$ & $\begin{array}{l}\text { Total } \\
\text { sugar } \\
(\mathbf{\%})\end{array}$ \\
\hline $\mathbf{1 .}$ & Amrapali & 19 & 0.15 & 22.61 & 4.32 & 4.78 & 12.72 & 17.5 \\
\hline $\mathbf{2 .}$ & Amin & 19.75 & 0.19 & 21.8 & 4.23 & 4 & 13.5 & 17.5 \\
\hline $\mathbf{3 .}$ & Chausa & 21.5 & 0.31 & 29.62 & 3.92 & 5.01 & 11.5 & 16.51 \\
\hline $\mathbf{4 .}$ & Dashehari & 21.4 & 0.32 & 30 & 3.81 & 5.5 & 10.5 & 16 \\
\hline $\mathbf{5 .}$ & Kakna(local) & 18.5 & 0.17 & 21.5 & 4.28 & 5.01 & 11.2 & 16.21 \\
\hline $\mathbf{6 .}$ & Krishnbhog & 20 & 0.19 & 18.58 & 4.23 & 4.74 & 12.46 & 17.2 \\
\hline $\mathbf{7 .}$ & Langra & 19 & 0.34 & 56.34 & 3.75 & 4.7 & 11.2 & 15.9 \\
\hline $\mathbf{8 .}$ & Mallika & 22 & 0.33 & 31.3 & 3.8 & 4 & 13.81 & 17.81 \\
\hline $\mathbf{9 .}$ & Sundri & 19.5 & 0.17 & 21.12 & 4.28 & 4.8 & 12.5 & 17.3 \\
\hline $\mathbf{1 0 .}$ & Totapari & 14.05 & 0.35 & 34 & 3.75 & 3.81 & 8.8 & 12.6 \\
\hline
\end{tabular}


Fig.1 Preparation of Pana and Nectar beverages

\section{FLOW CHART}

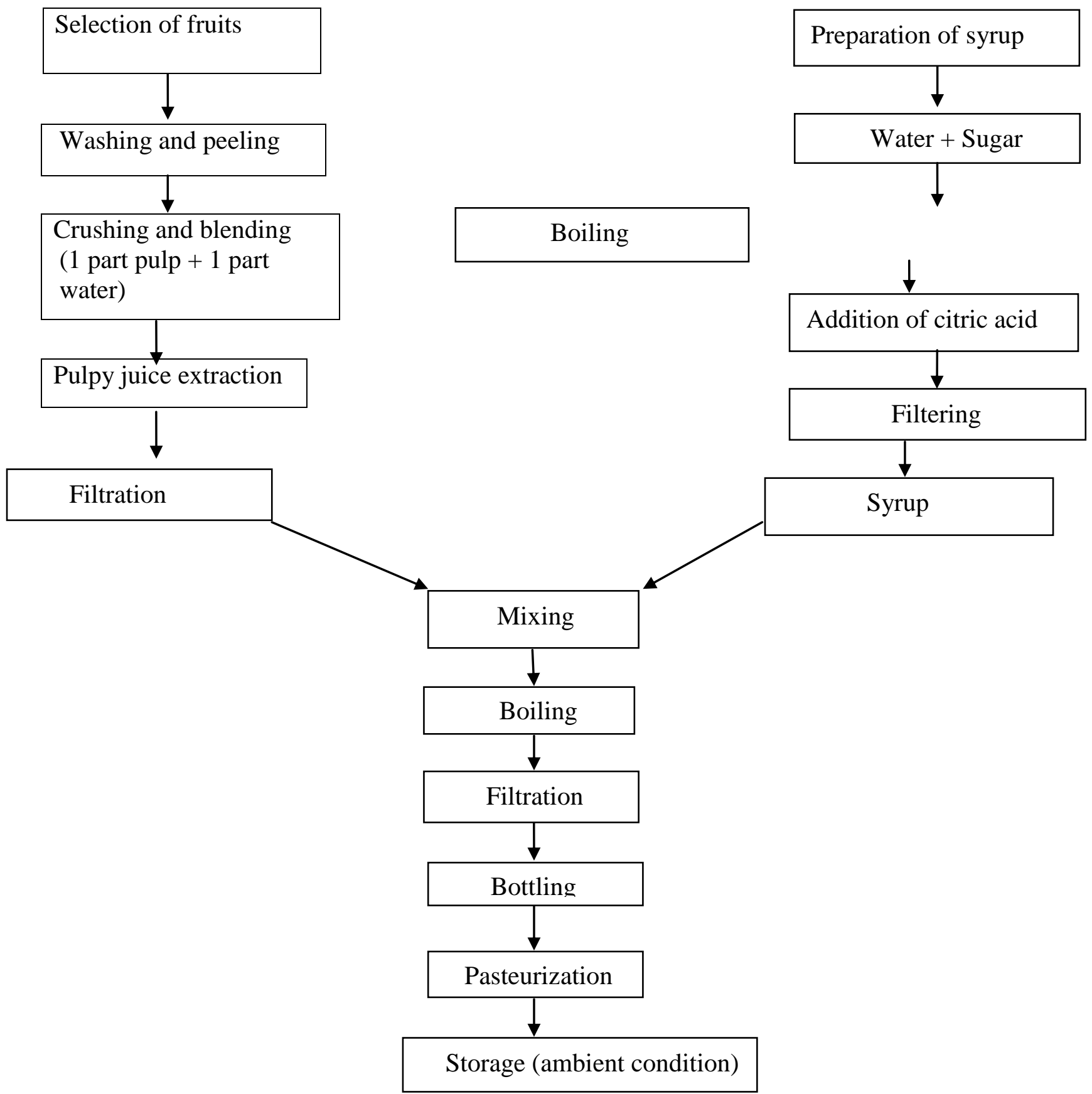


Ramdevputra et al., (2009)reported that the RTS beverage of $10 \%$ blended mango juice with lime and cardamom (10:2:0.006)+12\% TSS+0.3\% acidity retained significantly highest score for colour, taste, flavour, appearance, product setting at bottom and overall acceptance up to four months

In conclusion, different varieties for nectar and pana can be exploited for commercial use after concrete recommendations. Research work should be intensified for the processing of beverage based on locally available raw material as well as mango fruit.

A little attention has been made so far in the field of fruit processing technology in Chhattisgarh region. Hence, there is an urgent need to evaluate different varieties of mango for different preserved products of mango.

\section{References}

Anila, R. and Radha, T. 2003. Physicochemical Analysis of Mango Varieties under Kerala Conditions. J. Tropical Agri., 41: 20-22.

Chopra, C.S. 2014. Evaluation of mango (Mangifera indica L.) varieties for making RTS beverage Journal of Hill Agriculture 5(2): 198-202

Jain, V., Tiwari. B.L., Sharma, H.G. 1997. Evaluation of early maturing mango varieties for the preparation of beverages as nectar and RTS. Orissa Journal of Horticulture 25(1): 40-45.
Manchekar, MD., Mokashi, AN. Hegde, RV. Venugopal, CK and Byadgi, AS. 2011. Clonal Variability Studies in Alphonso Mango (Mangifera indica L.) by Genetic Divergence (D2) Analysis. Karnataka Journal of Agricultural Sciences 24 (4): 490-492.

Rabbani, A. and Singh, IS. 1988. Evaluation of local sucking mango varieties for beverage industry. Acta Horticulture 23(1): 715-720

Ramdevputra, M. V., Paradva, D. R., Kanzaria, D. R., Kakade, D. K. and Butani, A. M. 2009. Standardization of physical characteristics of recipe for preparation of ready-to-serve beverage (RTS) from Mango (Mangifera indica L.) cv. Kesar. Int. J. Agricultural Sciences, 5(2):378-382.

Roshan, RK. Pebam, N and Singh, DB. 2013. Physico-chemical analysis of polyembryonic mango cultivars under north India conditions. Acta Horticulture, 975 (IV): 351-354.

Roy, S.K., Singh, R.N. and Singh Rajendra. 1972. Studies on evaluation of some varieties of North India for processing as nectars. Indian Fd. Pack., 26(5):5-8

Shetty, M.S., Malathi, H.N., Nayandawam, Y.A.M. and Polly, V.H. 1978.Mango an industrial profile. Bul. C.F.T.R.I., Mysore.

Singh, I.S. and Dhawan, S.S.1983.Potentiality of various fruits for processing industry. Indian Fd. pack., 37:47-53.

\section{How to cite this article:}

Romila Xess, Arunima Tripathi, Meeta Bhuarya and Dileep Sahu. 2018. Evaluation of Physical and Chemical Composition of Mango Varieties for Nectar and pana. Int.J.Curr.Microbiol.App.Sci. 7(11): 2622-2627. doi: https://doi.org/10.20546/ijcmas.2018.711.299 